\title{
Application of Wasatiyyah in The Social Interaction of Plural Society in Malaysia
}

Khairul Azhar Meerangani, Mohammad Fahmi Abdul Hamid, Mohd Anuar Ramli, Norazmi Anas, Md Azzaat Ahsanie Lokman, Syeikh Muhd Taufiq A. Rashid

To Link this Article: http://dx.doi.org/10.6007/IJARBSS/v12-i1/12045

DOI:10.6007/IJARBSS/v12-i1/12045

Received: 03 November 2021, Revised: 08 December 2021, Accepted: 24 December 2021

Published Online: 15 January 2022

In-Text Citation: (Meerangani et al., 2022)

To Cite this Article: Meerangani, K. A., Hamid, M. F. A., Ramli, M. A., Anas, N., Lokman, M. A. A., \& Rashid, S. M. T. A. (2022). Application of Wasatiyyah in The Social Interaction of Plural Society in Malaysia. International Journal of Academic Research in Business and Social Sciences, 12(1), 1553-1562.

Copyright: (c) 2022 The Author(s)

Published by Human Resource Management Academic Research Society (www.hrmars.com)

This article is published under the Creative Commons Attribution (CC BY 4.0) license. Anyone may reproduce, distribute, translate and create derivative works of this article (for both commercial and non0-commercial purposes), subject to full attribution to the original publication and authors. The full terms of this license may be seen

at: http://creativecommons.org/licences/by/4.0/legalcode

Vol. 12, No. 1, 2022, Pg. $1553-1562$

Full Terms \& Conditions of access and use can be found at http://hrmars.com/index.php/pages/detail/publication-ethics 


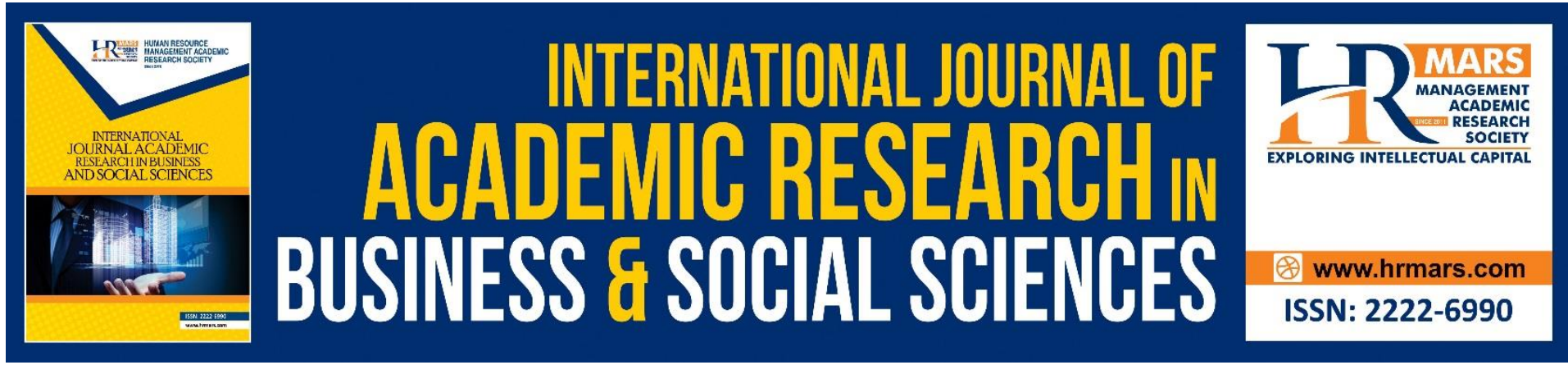

\title{
Application of Wasatiyyah in The Social Interaction of Plural Society in Malaysia
}

Khairul Azhar Meerangani, Mohammad Fahmi Abdul Hamid Academy of Contemporary Islamic Studies, Universiti Teknologi MARA Cawangan. Melaka

\author{
Mohd Anuar Ramli \\ Academy of Islamic Studies, Universiti Malaya
}

Norazmi Anas

Academy of Contemporary Islamic Studies, Universiti Teknologi MARA Cawangan Perak

\section{Md Azzaat Ahsanie Lokman}

Academy of Contemporary Islamic Studies, Universiti Teknologi MARA Cawangan Melaka

\author{
Syeikh Muhd Taufiq A. Rashid
}

Syariah Officer, Kedah Syariah Judiciary Departmen

\begin{abstract}
Malaysia is a country that manage to bring together various races and religions under one entity. This pluralism aspect has inevitably led to the interactions that transcend racial and religious boundaries. Therefore, this interconnection requires a strong foundation so that harmonious interaction can be manifested to maintain the harmony and unity of those living in a community that has established for so long. Thus, this study aims to shed light on the basic principles of plural interaction in Malaysia according to the perspective of the Qur'an. The study was conducted using a qualitative approach by highlighting the Qur'anic texts as well as the views of conventional and contemporary Muslim scholars before being analysed via inductive reasoning to formulate the Islamic perspective in driving plural interaction in Malaysia. This initiative is seen as an effort to strengthen and harmonise the social relations of people of various races and religions as well as clear the negative perceptions of the teachings of Islam, which by its nature emphasises the principles of universality ('alamiyyah), comprehensiveness (syumuliyyah), balance (wasatiyyah), and reflective (waqi'iyyah). Ultimately, the principles of plural interaction based on the Qur'an, Hadith, and the views of Muslim scholars by considering the current reality in the Malaysian context today is deemed to have provided a sustainable and holistic foundation as the core of social relations in Malaysia.
\end{abstract}

Keywords: Plurality, Interaction, Wasatiyyah, Harmony, Unity 


\section{Introduction}

Humans by their very nature are hard-wired to interact with their surrounding, which is deeply ingrained in the society. These interactions can take many forms, such as getting into conversations, sharing ideas, or even extending help. The segregation in the aspects of geography, politics, race, and religion that exists nowadays has led to a higher variety of interactions to fill in human relationships. As a country that brings together people of various races and religions, Malaysia is often acknowledged as a model of social unity at the international level. The establishment of the Department of National Unity and National Integration by the government in 2009 is deemed as one of the government measures and dedication to preserve unity among the Malaysian community. Although many efforts are designed and executed by the government to create harmony relationships between people of different races and religions, the level of interaction portrayed is still modest. The technical report prepared by a group of researchers on the reality and challenges of inter-religious relations in Malaysia demonstrates a hint of fragility in these recent interactions especially in addressing issues involving interests between religions (Azizan et al., 2014).

The national integration model that the government is trying to adopt somehow comes a dead end due to the lack of determination and commitment of certain parties in making it a success. Their state of ease to stay in low-level integration zones such as segregation and accommodation causes any attempt perceived to remove them from this comfortable space is deemed as a form of threat to their own religious position and interests. Thus, the effort to create a Malaysian nation using a high degree of integration model such as amalgamation seems a bit difficult to apply for the time being because it requires the sacrifice of all parties to set aside the interests of their religion, lineage, and culture (Mohd \& Mohammad, 2012). However, the adoption of the accommodation model (low level integration) is still practical to implement with some improvements and modifications.

Most of the studies conducted on this issue discuss and are more focused to prepare a model of unity based on race and ethnicity rather than religion. Rahimin (2011) emphasises the need for the implementation of interfaith dialogues in Malaysia as one of the mechanisms in establishing racial and religious unity. Khadijah and Herzali (2008) stated that Article 11 of the Federal Constitution is the foundation that drives the religious tolerance policy in Malaysia. Furthermore, the 'urf majmuk' model introduced by Mohd \& Mohammad (2011) views the culture of open house to celebrate multireligious festivals in Malaysia plays a role in building a foundation of relationship between people of plural society in Malaysia. In fact, the initiative to achieve harmonious interaction between those in the plural society has long been the main agenda of the government to create stability and unity among the community.

However, the change in political demographics since the 12th GE in 2008 has witnessed the relationship between believers of different religions in Malaysia enters a new dimension. There are various demands that are inundated with elements of provocation triggered by certain parties for the purpose of causing tension in society. The approach utilised by the government in managing the relationship between religious believers in Malaysia so far shall be re-evaluated based on the reality today. This is to ensure that the relationship established fosters unity and harmony instead of division and enmity.

- Thus, this study is conducted to introduce the foundation of unity among believers based on the wasatiyyah perspective, which is universally recognised as an added value to reinforce the existing foundation. 


\section{Research Methodology}

This study utilises a qualitative approach in the process of data collection and data analysis. Qualitative research focuses on efforts to obtain non-numerical information (Cresswell, 2005) that can provide information about the background of a matter in detail. Thus, this study is oriented towards qualitative methods through analysis of written data to sum up the perspective of the Qur'an on plural interactions in Malaysia. The information used in this study was obtained via inductive approach by scrutinising the primary and secondary sources that are relevant to the issues in this study, and the data inferred reinforce and explain the roots of the problems. Data analysis was conducted using deductive approach by understanding the arguments and opinions of Muslim scholars and anything derived thereof which are relevant to the area of concern of this study. This approach is used to describe the problem or phenomenon that is currently reviewed and then the findings of the study shall be used to come up with specific conclusions that are appropriate to the research problems. The data collected after inductive and deductive methods are formulated to address the research questions, thus summarising the basic principles of plural interaction in Malaysia according to the Islamic perspective.

\section{Plurality From Islamic Perspective}

Developing an understanding of the background of cultural and religious diversity is significant in producing a more harmonious and tolerant relationship. The trait of mutual understanding helps to create a society that respects each other. To realise the desire to establish a foundation of good understanding, all parties should realise that the foundation of pluralism in human creation is not for the purposes of division and enmity, but it is more to provide a space for harmonious interaction (Khairul, 2016). This is indeed in line with the following verse:

$O$ mankind, We have created you from a male and a female, and made you into races and tribes, so that you may identify one another. Surely the noblest of you, in Allah's sight, is the one who is most pious of you. Surely Allah is All-Knowing, All-Aware. (alHujuraat, verse 13)

According to al-Qurtubi (2006), the verse was revealed during the opening of Mecca, following the order of the Prophet SAW to Bilal bin Rabah to pronounce the call to prayer on top of the Kaaba. Such action did cause negative reaction out of Quraysh renowned leaders who were still overwhelmed with their racist attitude. 'Attab bin Asid, among others said, "Praise be to Allah my father has dead without having to witness this event." Al-Harith bin Hisham, on the other hand, said, "Muhammad had run out of followers that he has to appoint a 'black crow' to call for prayer". The insults due to caste was eventually admonished by Allah SWT through a verse. According to al-Baghawiy (2002), each mankind come from the same creation, all of us are the descendants of Adam and Eve. They in turn have evolved, yet their lineages are associated with each other; either close or distant. The word syu'ub شعوب) refers to the distant kinship while qaba'il (قبائل) refers to the close kinship, which is the subset of syu'ub itself (al-Tabari, t.th).

Ibn Kathir (1997) explains that syu'ub (شعوب) is more general than qaba'il (قبائل), and qaba'il (قبائل) has its own clans or degrees such as fasa'il (فصائل), 'asya'ir (عشائر), 'ama'ir

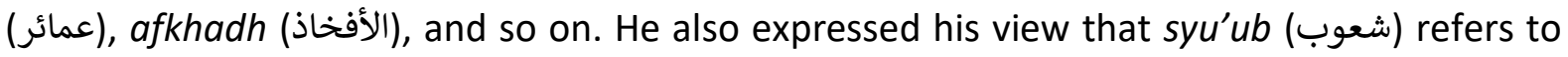
the 'ajam (عجم) clan which is not from Arab, while qaba'il (قبائل) are indeed the fractions of the Arab tribes. Al-Baghawiy (2002) also interprets the same, in which syu'ub is deemed as ru'us al-qabail (رؤوس القبائل), from which it will split into smaller tribes and the next. Thus, the 
verse signifies humans living on earth come from the same lineage, that is Adam pbuh. When Adam and Eve began to have children, the next generations are developed and divided into races, ethnicities, tribes, clans, families, and others. The process of 'clanism' that has been going on for a long time until this day may result in the existence of new religions and beliefs, which are ultimately different from the original religion of nature (Islam), as entrusted to Adam pbuh.

In addition, the same verse does explain that the philosophy behind the concept of human pluralism is oriented towards the principle of ta'aruf (تعارف). The particle lam (تلامو) placed on the verb ta'arafu (تعارفوا) refers to lam al-ta'lil which means because, for, or so that, does carry the meaning of the direction upon the difference. The verb ta'arafu تعاروفاع) in terms of the knowledge of al-sarf comes from wazan or the tafa'ala (تفاعل) pattern, which means a function as an interconnection or relationship with one another (Ashafizrol, 2015), or in the translation of the Qur'an referred to as 'mutual'. Al-Tabari (t.th) explains that the word li ta'arafu (لتعارفوا) refers to getting to know each other. Al-Baghawiy (2002) further highlights that the creation of various races and tribes is not for the purpose of pride on the privileges available to certain parties. Al-Sa'diy (2002) also expands the theme of ta'aruf as helping each other (تناصرف), inheriting (توارث), and fulfilling the rights of relatives (تنارف) القعار) (بحقوق الأقارب (تصار), as the purpose of God creating diversity in humans. Thus, the context of ta'aruf (تعارف) is not limited to only knowing or getting to know each other, but it has a broader context that includes interacting with each other, helping each other, respecting, protecting rights of living creatures, and others. This philosophy is not exclusive to relationships between Muslims, but also includes the non-Muslims to realise the harmony and wellbeing of humans worldwide.

\section{Principles of Wasatiyyah in The Social Interaction}

In Malaysia, the mass migration of ethnic groups other than Malays due to the colonial policy at that time has resulted in pluralism in society of the Malay Land, which saw the interactions across racial and religious boundaries. However, the "divide and rule" policy pursued by the colonialists in the social and economic aspects has created segregation in the relationships between the communities. This in fact limits the opportunities for inter-religious and cultural interaction, thus stirs up the elements of preconceived notion, prejudice, and stereotypes among them. The dominance of a particular race or ethnicity over a religion also influences social interaction between the plural society in Malaysia. The competition that arises as a consequence of the efforts to portray the religious way of life for a certain race, which at first is related to racial issues, sometimes also resorts to religious conflicts.

Although the government has drafted and implemented several initiatives to improve the degree of relationships between religious believers in Malaysia, some suggestions are indeed crucial to be highlighted to improvise the model implemented so that the approach used works wonder. The low degree of maturity involving interfaith believers in Malaysia in building interactions among them requires reformation and re-evaluation of some guidelines so they are consistent with the current realities in Malaysia. Islam has provided several foundations that are deemed feasible to be practised in building harmonious interaction between believers of different religions, namely:

\section{a) Wise Communication}

Interaction requires communication that takes place between human beings, be it verbal or non-verbal. Communication in the form of daily conversations, discussions or amicable talks 
(dialogues) shall take into account the background and position of all parties involved so that the communication does not stray from the objectives that have been stipulated. In this regard, Islam has shown several communication methods that are deemed appropriate to be applied in creating effective interactions. According to Sayyid (1996), wise communication requires observation and careful evaluation of the current situations and reality of the target group using relevant and effective communication techniques. Giving advice is applied by having gentle communication to touch the human heart in lieu of threats and restrictions that can embarrass them for their actions.

al-Razi (1981) stated that a communication shall be adjusted according to the background and suitability of the listener. He categorises the recipients of information into three groups as follows:

i) Intellectuals who need to have proper arguments and facts that can trigger their minds to think about the truth of the argument because they have a high level of thinking and analysis. This method is known as meticulous and intelligent communication (الحكمة).

ii) For the public whom the level of thinking is moderate, this group needs to be exposed to the inculcation of religious values in relation to morals and ethics in general, either through words or behaviour. This is because these groups are easier to convince and influence once the common principles of life for the benefits of many are shared. This method is known as exemplary communication (الموعظة الحسنة).

iii) There are antagonists, where most of their arguments revolve around the attempt to challenge a concept without really seeking for truth and consensus. This group of people shall be dealt with via debates that are able to rebut their arguments as well as reiterate the strength of our own arguments using the most accurate, applicable, and well-founded technique. This method is known as argumentative communication (الجدال).

The mastery of the relevant communication methods is essential to develop a harmonious connection and avoid any form of uncertainties that may arise because of mistakes in adopting any communication methods while having the interaction.

The use of words or approaches that are improper to the level and situation of some parties would affect the viability of the communication direction. It is interesting to acknowledge and internalise the wisdom of Rasulullah SAW in using different approaches when dealing with different individuals and groups such as the Bedouin tribe, ahl al-kitab (People of the Book), hypocrites, nobles and leaders, children and women, and Muslims with different backgrounds and thinking in its entirety. It is this skill that ultimately contribute to the daqwah (spread of Islam) effectively and extensively.

\section{b) Tolerance}

In reality, human beings are created to grow up and live in different environments. Differences in terms of politics, geography, economy, culture, and religion require high level of acceptance and tolerance. Thus, any attempt to pressure the human beings to follow certain aspects, especially in terms of religion, this is beyond human capability. The existence of religious diversity is not as a form of domination and power over other religions, but this serves as a process to build tolerance and get to know wach other. Islam does not accept the concept of free religion because each religion has its own doctrines that shall be followed and complied with by each of its believers (Ramli, 2003). On the other hand, Islam recognises the concept of freedom of religion where the practice of any religions is allowed on the basis of 
mutual respect and embrace each other's differences provided there is no element of interferences and disregard for the doctrines of any other religions in the public without any limit (Khadijah \& Herzali, 2008).

This is in line with the provisions outlined in the Federal Constitution where although Islam is recognised as the official religion of Malaydia, but other religions can still be practised without any interference. A clear understanding of this concept shall engender a true spirit of tolerance among the believers of various religions, thus in turn lead to a solid unity. Yusuf (2001) has proposed four principles that are practical to be adopted by Muslims as the key policies in creating tolerance as follows:

i) Every Muslim shall acknowledge and recognise the basis of human dignity regardless of religion, race, and skin colour.

ii) Every Muslim shall realise and accept that the existence of different religions are part of the rules that Allah has set to enable people to make a choice to accept or abandon a belief based on their understanding and beliefs.

iii) Every Muslim shall not be hostile to non-Muslims due to their disbelief and adhere to the principle of religious freedom.

iv) Every Muslim shall believe that being fair and fulfilling the rights of fellow human beings despite different races and religions is part of God's command that must be implemented.

If these principles are internalised and applied properly, for sure there shall be a group of people who can accept and celebrate the diversity that exists among them without compromising the peace and harmony in their surroundings. During the Islamic rule in Madinah, the Prophet SAW did not interfere with the Jews, in fact the latter have their own religious and academic institutions known as Bayt al-Midras (Ibn Hisham, t.t). The Jews are free to manage and carry out their activities without any restrictions as long as they do not pose a nuisance and threat to Muslims. This has indeed reflected the prestige of Islam as a religion that celebrates human rights. Likewise, after the battle of Khaybar where the companions had confiscated the pages of the Torah due to huge deviations and lies against Allah and His Messenger highlighted in the Book, when the Jews complained about the matter to the Prophet SAW, he eventually ordered the companions to return the Book to them as a form of respect for the rights and freedom of religion (al-Waqidi, 1989).

c) Impartiality

The concept of impartiality shall be embraced regardless of racial and religious differences. Islam emphasises the need to be impartial in all matters of life without being influenced by certain sentiments or backgrounds. This is because impartiality is an element that is the core of community life. Islam strongly forbids any form of cruelty to fellow human beings, especially the one that is built upon certain sentiments (Ibn Kathir, 1999). The implementation of justice is not solely theoretical but has been absorbed into the thoughts and actions of the companions, urging them to remain impartial even after the passing of the Prophet SAW. This is reflected during the rule of Caliphate Ali ibn Abi Talib when he lost his armour which was later found to be in the hands of a Jewish man. Both had complained about this matter to the then supreme judge, Syuraih. Based on the evidence and proof, it was resolved that the armour belongs to the Jewish man. Looking at this event, it is crystal clear that Islam promotes justice. For the Jewish man, justice is served even his opponent at that time was the ruler of the Islamic territory. Later, the Jewish man embraced Islam because of being impressed and he then returned the armour to Caliphate Ali (Abd al-Mun'im, 1988). The event proves that 
the concept of impartiality in Islam is indeed pragmatic, where the implementation is fair to all, even to enemies or those of different religions.

\section{d) Charity}

By its nature, human instincts shall always be driven to do good and be virtuous to each other. This concept is carried through regardless of the religious differences to empower the relationships that are built upon noble and remarkable values. Islam does not restrict any form of welfare distribution to believers of different religions either in terms of economy or social. The relationship of Muslims with people of other religions is not only built upon the values of upholding harmony and peace, but also encapsulated in a broader concept, which is care and welfare for all. Rasulullah SAW once visited a Jewish teenager who was one of the helpers to serve him. The caring and responsible nature of the Prophet eventually has attracted the youth to embrace Islam (al-Bukhari, 2002). Moreover, Rasulullah SAW has ordered Asma binti Abu Bakar to keep serving and give good treatment to her mother even the latter is not a Muslim. This clearly demonstrates that religious differences are not an obstacle to nurture social welfare in a multi-racial and multi-religious society.

Although Allah forbids any form of obedience to parents of different religions in religious matters, but a child is still responsible to pay the rights of their parents in the best and appropriate manner. Such high degree of care will establish a strong relationship as well as melt away even a speck of emotional turmoil lurking in the heart. Also, Islam places great emphasis on giving charity to neighbours, it has been narrated that Abd Allah ibn Amru one of the Prophet SAW companions once slaughtered a goat and asked his assistant whether the meat had been given to their Jewish neighbour. He repeated the question twice and highlighted the message of the Prophet SAW to treat the neighbours well. From the perspective of Al-Qardawi (1992) in charity, Islam advocates the need to be gentle towards the weak among non-Muslims, extend assistance to the poor and needy, provide food and clothing to the needy, associate with them in a kind and polite manner, pray that they are given guidance to the religion of Islam, advise them in worldly affairs, preserve their dignity and property from any threat as well as help them from any element of tyranny.

\section{e) Harmony}

Islam forbids any form of vile and nasty words against the practices and doctrines of any religion without having a proper argument in a decent manner. This is because any kinds of provocation will only incite a more extreme response, which can eventually lead to more profound quarrels and hostility. Islam forbids any speech that is inundated with insults and derogatory words to the perpetrator in public, whether an offence is committed by the perpetrator or not (al-Fayyumi, 1987). Ibn Kathir (1999) states that Muslims are forbidden to taunt and despise the worship of the polytheists in Mecca to avoid from any kind of aggravated insults as a form of retaliation. This prohibition is outlined not for fear of incoming threat but it is indeed the ethics for Muslims in dealing with people of various religions.

Muslims are prohibited from initiating any form of provocation for any reason whatsoever to avoid any great harm out of the blue. Rasulullah SAW himself was once provoked by a group of Jews who mocked the the way greeting people by changing from assalamu'alaikum (peace be upon you) to assamu'alaikum (death/disaster upon you). A'isyah RA who heard such mocking had responded to the provocation by praying for misfortune and a curse of evil on them but was reprimanded by the Prophet. Although A'isyah initially questioned Rasulullah SAW of his action which is deemed to be defensive, she eventually 
listened to his explanation that such provocation had already been responded just enough. This shows the high degree of patience possessed by the Prophet SAW despite facing extreme provocation and insolence from the opponents.

Therefore, it is the responsibility of every believer to display an amount of respect to those of different religions based on the concept of "agree to disagree". Any elements that can tear down harmony in society such as extremism, chauvinism, and fanaticism shall be immediately thwarted and curbed to ensure the peace and harmony of this multi-religious society can be realised (Mohd \& Mohammad, 2011). Each party shall also refrain from coming up with certain demands or objections, especially in relation to the main doctrines and teachings of other religions because it is feared that such actions will only elicit unprecedented counter attacks. This is because religious issues in Malaysia are indeed deemed as sensitive issues because they have the potential to be exploited by any party to create chaos in the society (Khairul et.al., 2020).

\section{Conclusion}

The great relationship formed between the followers of various religions in Malaysia shall always be maintained to ensure the harmony of people living in the society. This situation requires cooperation of all parties as a team to undergo an integration process that is nationoriented by its nature. Sharing and adherence to admirable values and norms is agreed upon by all human beings across racial and religious boundaries. Therefore, these fundamentals shall always be used as a guide in the framework of establishing an interaction that is not merely rhetorical but can be translated to the concept pluralism and diversity that has existed in Malaysia in a more solid and integrated form. Any threat that is deemed to destruct the foundation of harmony in society shall be eradicated right away, either through campaigns and dialogues or law enforcement to preserve the stability and harmony between religious communities in Malaysia.

\section{Acknowledgement}

This paper is one of the research output made for fulfilling the TEJA Research Grant (Universiti Teknologi MARA Cawangan Melaka) requirement under the project entitled, 'Cross-Cultural Practices in a Pluralistic Society in Melaka' numbered GDT2021/1-4.

\section{References}

Al-Baghawiy, A. M. H. M. (2002). Ma'alim al-Tanzil. Lubnan: Dar Ibn Hazm.

Al-Bukhari, M. I. (2002). Sahih al-Bukhari. Beirut: Dar Ibnu Kathir.

Al-Fayyumi, A. M. A. (1987). Misbah al-Munir. Beirut: Maktabah Lubnan.

Al-Qurtubi, M. A. B. (2006). al-Jami' li Ahkam al-Quran. Beirut: Mu'assasah al-Risalah.

Al-Qusyairi, M. H. (1991). Sahih Muslim. Beirut: Dar al-Kutub al-'llmiyyah.

Al-Razi, F. D. (1981). Mafatih al-Ghayb. Beirut: Dar al-Fikr.

Al-Sa'di, A. R. N. (2002). Tafsir al-Sa'di. Riyad: Maktabah Dar al-Salam.

Al-Sirjani, R. (2010). Fann al-Ta'amul al-Nabawi ma'a Ghayr al-Muslimin. Qahirah: Dar Aqlam. Al-Tabari, M. J. (t.th). Jami' al-Bayan 'an Ta'wil Ay al-Qur'an. Qahirah: Maktabah Ibn Taimiah. Al-Waqidi, M. U. (1989). al-Maghazi. Beirut: Dar al-A'lami.

Ashafizrol, A. H. (2015). Matan al-Ajurrumiyyah. Alor Setar: Alasfiyaa Sdn. Bhd.

Azizan, B., Zaid, A., Ahmad, T. T., Jayum, J., \& Sarjit, S. D. S. (2014). Isu dan Cabaran Hubungan antara Penganut Agama di Malaysia, Laporan Teknikal, diakses dari 
https://www.researchgate.net/publication/288827698_KAJIAN_ISU_DAN_CABARAN_ HUBUNGAN_ANTARA_PENGANUT_AGAMA_DI_MALAYSIA.

Cresswell, J. W. (2005). Educational Research: Planning, Conducting and Evaluating Quantitative and Qualitative Research. New Jersey: Pearson Education Inc.

Ibn Hisyam, M. A. M. (t.th). al-Sirah al-Nabawiyyah. Beirut: Dar al-Qalam.

Ibn Kathir, I. U. (1997). Tafsir al-Qur'an al-'Azim. Riyad: Dar al-Tayyibah.

Khadijah, M. H., \& Herzali, M. H. (2008). Toleransi Beragama dan Amalannya di Malaysia: Rujukan kepada Artikel 11 Perlembagaan Persekutuan Malaysia. Jurnal Usuluddin 27 (1): 81-92.

Khairul, A. M. (2016). Isu Semasa Terhadap Hubungan Sosial Dengan Non Muslim di Malaysia Daripada Perspektif Hukum Islam. Tesis, Akademi Pengajian Islam Universiti Malaya.

Khairul, A. M., Muhammad, I. R., \& Syamsul, A. M. (2020). Pendekatan Wasatiyyah Dalam Interaksi Inter-Agama di Malaysia. MANU: Jurnal Pusat Penataran Ilmu dan Bahasa 31(2): 19-46.

Mohd, A. R., \& Mohammad, A. J. (2012). Prinsip Hubungan Sosial Bagi Menangani Konflik Dalam Masyarakat Malaysia Berteraskan Islam. Jurnal Peradaban 5 (1): 49-71.

Mohd, A. R. \& Mohammad, A. J. (2011). 'Uruf Majmuk: Konsep Dan Amalannya Dalam Masyarakat Majmuk di Malaysia. Jurnal Figh 8 (1): 45-64.

Rahimin, A. A. R., Mohd, A. R., Paizah, I. \& Hayati, M. D. (2011). Dialog antara Agama : Realiti dan Prospek di Malaysia. Kajian Malaysia 29 (2). 91-110.

Sayyid, Q. (1996). Fi Zilal al-Qur'an. Beirut: Dar al-Syuruq.

Subhi, S. (1975). al-Ma'alim al-Syari'ah al-Islāmiyyah. Beirut: Dar al-'Ilm al-Malayin.

Yusuf, Q. (1992). Ghayr al-Muslimin fi al-Mujtama' al-Islami, Qahirah: Maktabah Wahbah. 